\title{
Associations of the polymorphisms in long non-coding RNA H19 with hepatocellular carcinoma risk in a Southern Chinese population
}

\author{
Zhifeng Lin ${ }^{1,2, *}$, Junguo Zhang ${ }^{1, *}$, Xiaohui $\mathrm{Ji}^{1}$, Lucheng $\mathrm{Pi}^{1}$, Nana Tian ${ }^{1}$, Xinqi Lin ${ }^{1}$, \\ Li Liu ${ }^{1}$, Sidong Chen ${ }^{1}$, Xinfa Yu ${ }^{3}$ and Yanhui Gao ${ }^{1}$ \\ ${ }^{1}$ Department of Epidemiology and Health Statistics, School of Public Health, Guangdong Pharmaceutical University, \\ Guangzhou, China \\ ${ }^{2}$ Medical Record Department of The Third Affiliated Hospital of Guangzhou Medical University, Guangzhou, China \\ ${ }^{3}$ Shunde Hospital of Southen Medical University, Guangzhou, China \\ *These authors contributed equally to this work \\ Correspondence to: Yanhui Gao, email: gao_yanhui@163.com \\ Xinfa Yu, email: yuxfa@126.com
}

Keywords: hepatocellular carcinoma; HCC; LnCRNA; H19; polymorphisms

Received: September 15, 2017 Accepted: October 25, $2017 \quad$ Published: January 02, 2018

Copyright: Lin et al. This is an open-access article distributed under the terms of the Creative Commons Attribution License 3.0 (CC BY 3.0), which permits unrestricted use, distribution, and reproduction in any medium, provided the original author and source are credited.

\section{ABSTRACT}

Background: Overexpression of $\mathrm{H19}$ long non-coding RNA (IncRNA) has been observed in hepatocellular carcinoma (HCC), however, the role of $H 19$ polymorphisms in the development of HCC was still unclear. Therefore, in this study, we aimed to explore whether the $\mathrm{H} 19$ polymorphisms were related to the susceptibility of HCC.

Materials and Methods: A case-control study of 625 cases and 621 controls was conducted to investigate genetic associations of three potentially functional variants in $\mathrm{H19}$ (rs2839702, rs2067051 and rs2075745) with HCC risk in a Southern Chinese population.

Results: After adjustment for age, gender, smoking status, drinking status, HBsAg status, and family history of cancers, three $\mathrm{H} 19$ polymorphisms were not associated with HCC risk under any genetic models. The odds ratio (OR) per risk allele for HCC was $1.03(95 \%$ confidence interval $[95 \% \mathrm{CI}]=0.94-1.13)$ for rs2839702, 1.05 (95\% CI $=0.96-1.16)$ for rs2067051, and $1.04(95 \%$ CI $=0.95-1.14)$ for rs2075745, respectively. No significant associations were also observed in the stratified analysis, haplotype analysis and combined effect analysis.

Conclusions: Our study indicated that no association of polymorphisms (rs2839702, rs2067051 and rs2075745) in long non-coding RNA H19 with HCC. Further larger population-based case-control study and a global view to the genetic component of $\mathrm{H19}$ would be required to identify the causal genetic polymorphisms for HCC.

\section{INTRODUCTION}

Hepatocellular carcinoma (HCC) is one of the most common primary malignancy and the third leading cause of cancer-related death [1]. Although the treatment of HCC has made great advance, the long-term survival still remains quite low, with the 5 year survival rate of $22 \%$ [2]. Thus, elucidation of the etiological factors for the development of HCC would be of great help to develop the effectively preventative and therapeutic approaches for HCC. It is well established that the occurrence and progression of $\mathrm{HCC}$ is a complicated process, in which multiple genetic and environmental factors are involved [3]. Among the risk factors, genetic basis could predispose to the HCC development and explain why only a fraction of individuals actually develop HCC when exposed to the same risk environment. In spite of great effort for the research of hepatocellular carcinogenesis, the underlying 
molecular mechanisms contributing to HCC need to be further elucidated.

Recently, high throughput transcriptome analysis has revealed that up to $98 \%$ of human genome would transcribe into non-coding RNA. Among them, the long non-coding RNAs (lncRNAs), more than $200 \mathrm{bp}$ in length [4], are broadly concerned for their pivotal role in the regulation of gene expression. Recent studies have identified the participant of lncRNAs in a wide range of biological processes, including proliferation, cell cycle, apoptosis, differentiation and invasion [5-7], and that emphasized the prominent effect of lncRNAs in cancer incidence and progression.

H19, located on chromosome $11 \mathrm{p} 15.5$, has attracted much interest in research of cancer etiology. The H19 is a paternally imprinted oncofetal gene and does not encode for a protein, but instead codes for a capped, spliced and polyadenylated $2.7 \mathrm{~kb}$ RNA [8, 9]. Emerging evidence demonstrated the relationship between an aberrant expression of H19 and HCC. For example, the study by Matouk et al. [10] suggested that HCC tumors transfected with $H 19$ siRNA exhibited significant inhibition of tumor growth, and in certain cases, there was complete inhibition of tumor formation. There was a $82 \%$ decrease of mean tumor weights and mean tumor volumes in the two transfected cell lines. Thus, H19 exerts a tumor suppressor role in hepatocellular carcinogensis.

Multiple lines of evidence revealed that the potentially functional consequences of the genetic polymorphisms in lncRNAs affecting their structure and molecular function. The polymorphisms in the lncRNA H19 have been investigated in breast, bladder, gastric, lung, colorectal and ovarian cancer [11-16]. However, no studies to date have reported on the association between H19 polymorphisms and the risk of HCC. Therefore, we used bioinformatics tools to screen out three potentially functional polymorphisms of $H 19$ (rs2839702, rs2067051 and rs2075745). And then we carried out a hospital-based case-control study of 625 patients with HCC and 621 cancer-free controls in a Southern Chinese population to explore the role of three polymorphisms in susceptibility to $\mathrm{HCC}$ and the effect of three polymorphisms on HCC progression.

\section{RESULTS}

\section{Characteristics of the study subjects}

The characteristics of $625 \mathrm{HCC}$ cases and 621 controls are summarized in Table 1. The distributions of gender and age between cases and controls were similar $(P>0.05)$. As expected, more HBsAg positive status proportion was observed among HCC cases compared with controls $(76.21 \%$ and $31.72 \%$, respectively). Significant associations were also seen between smoking, drinking, tumor family history and HCC (all $P<0.01$ ). The proportions of TNM stages of I/II and III/IV were $13.76 \%$ and $70.72 \%$ in HCC cases, respectively. Furthermore, the proportions of metastasis and non-metastasis were $13.60 \%$ and $81.92 \%$, respectively. Besides, the proportions of cancer embolus and non-cancer embolus were $10.24 \%$ and $84.80 \%$, respectively.

\section{Association analysis between the polymorphisms in $\mathrm{H} 19$ and $\mathrm{HCC}$ incidence risk}

For all the three polymorphisms, genotype frequencies in controls were in Hardy-Weinberg equilibrium (Supplementary Table 1). The distributions of genotypes and alleles in cases and controls were presented in Table 2. No statistically significant genetic association with HCC was found for all the polymorphisms (rs2839702, rs2067051 and rs2075745) under any genetic models. The odds ratio (OR) of per risk allele for HCC was $1.03(95 \%$ confidence interval $[95 \% \mathrm{CI}]=0.94-1.13)$ for rs2839702, 1.05 (95\% CI = 0.96-1.16) for rs2067051, and $1.04(95 \% \mathrm{CI}=0.95-1.14)$ for rs2075745. Moreover, further stratified analysis also showed no association between the polymorphisms and HCC risk under the recessive model for the maximum effect of rs2067051 (Table 3). No associations were also seen in the rest two polymorphisms under the recessive model (Supplementary Table 2). Additionally, the interaction analysis between gene and environment was performed to explore their role on HCC susceptibility. However, no significant interaction was observed between the rs2067051 and environmental factors (Table 3). Meanwhile, there were no significant interaction effect for rs2075745 and rs2839702 (Supplementary Table 2).

To investigate the combined genetic effect, haplotype analysis was conducted for the rs2839702, rs2067051, and rs2075745. Three haplotypes were constructed, of which, the haplotype ACA was the highest frequency (Table 4). However, no significant association of the haplotype was found with the HCC risk. We also compared the carrying numbers of risk alleles between cases and controls, but did not find any statistically significant result (Table 5).

\section{The association analysis between the polymorphisms and clinicopathological characteristics of $\mathrm{HCC}$}

There were also not any statistically significant associations between the polymorphisms and the clinicopathological characteristics of HCC, including the TNM stage, metastasis and cancer embolus (Table 6).

\section{DISCUSSION}

In the present study, we conducted a hospital-based case-control study in a Southern Chinese population 
Table 1: Characteristics of the patients with hepatocellular carcinoma and controls

\begin{tabular}{|c|c|c|c|}
\hline Variables & $\begin{array}{c}\text { Controls (\%) } \\
\quad N=621\end{array}$ & $\begin{array}{c}\text { Cases }(\%) \\
N=625\end{array}$ & $\boldsymbol{P}^{*}$ \\
\hline Mean age, years (SD) & $58.5(12.1)$ & $58.8(11.9)$ & 0.608 \\
\hline Gender & & & 0.707 \\
\hline Male & $535(86.15)$ & $543(86.88)$ & \\
\hline Female & $86(13.85)$ & $82(13.12)$ & \\
\hline HBsAg status & & & $<0.001$ \\
\hline Positive & $197(31.72)$ & $477(76.21)$ & \\
\hline Negative & $424(68.28)$ & $148(23.79)$ & \\
\hline Smoking status & & & $<0.001$ \\
\hline Yes & $352(56.68)$ & $425(68.00)$ & \\
\hline No & $269(43.32)$ & $200(32.00)$ & \\
\hline Drinking status & & & $<0.001$ \\
\hline Yes & $279(44.93)$ & $351(56.16)$ & \\
\hline No & $342(55.07)$ & $274(43.84)$ & \\
\hline Family history ${ }^{\mathrm{a}}$ & & & $<0.001$ \\
\hline Yes & $86(13.85)$ & $168(26.88)$ & \\
\hline No & $535(86.15)$ & $457(73.12)$ & \\
\hline \multicolumn{4}{|l|}{ TNM stage } \\
\hline $\mathrm{I}+\mathrm{II}$ & & $86(13.76)$ & \\
\hline $\mathrm{III}+\mathrm{IV}$ & & $442(70.72)$ & \\
\hline NA & & $97(15.52)$ & \\
\hline \multicolumn{4}{|l|}{ Distant metastasis ${ }^{\mathrm{b}}$} \\
\hline Yes & & $85(13.60)$ & \\
\hline No & & $512(81.92)$ & \\
\hline NA & & $28(4.48)$ & \\
\hline \multicolumn{4}{|l|}{ Cancer embolus ${ }^{\mathrm{b}}$} \\
\hline Yes & & $64(10.24)$ & \\
\hline No & & $530(84.80)$ & \\
\hline NA & & $31(4.96)$ & \\
\hline
\end{tabular}

Abbreviations: NA, Not available; SD, Standard deviation.

*The $P$ values were calculated by using the student's $t$ test or $\chi^{2}$ test.

aThe subjects have a family history of malignancy in the first-degree relatives.

${ }^{b}$ Distant metastasis and cancer embolus were determined at first diagnosis of hepatocellular carcinoma.

to explore the potential association between the $H 19$ polymorphisms and HCC risk. Our results demonstrated that rs 2839702 , rs2067051 and rs2075745 in $H 19$ were not associated with the risk of HCC incidence or progression among Chinese population, and negative results were also observed in all of the subgroups stratified by gender, HBsAg status, smoking status, drinking status and family history.

Recently, accumulating evidences suggested that $H 19$ was up-regulated in a variety of cancer types, including esophageal cancer [18], bladder cancer [19], colorectal cancer [20] and breast cancer [21]. Previous studies have indicated that $H 19$ involves in the complex biological process of oncogenesis [22-24]. Liang et al. reported that $\mathrm{H} 19$ functioned as a competing endogenous RNA (ceRNA) for miR-138 and miR-200 and antagonized their functions, leading to the de-repression of their endogenous targets Vimentin, ZEB1, and ZEB2, all of which were core marker genes to promote epithelialmesenchymal transition (EMT) in colorectal cancer [25]. Furthermore, $H 19$ has the potential to produce the "91H RNA", which regulates insulin like growth factor 
Table 2: The association between the polymorphisms of $\mathrm{H19}$ and HCC susceptibility in the casecontrol study

\begin{tabular}{|c|c|c|c|c|c|c|}
\hline Genotypes & $\begin{array}{c}\text { Controls (\%) } \\
N=621 \\
\end{array}$ & $\begin{array}{c}\text { Cases (\%) } \\
N=625 \\
\end{array}$ & $\chi^{2}$ & $P$ & $\begin{array}{c}\text { Crude OR } \\
(95 \% \text { CI) } \\
\end{array}$ & $\begin{array}{c}\text { Adjusted OR } \\
(95 \% \text { CI })^{*}\end{array}$ \\
\hline \multicolumn{7}{|l|}{ rs $2839702^{a}$} \\
\hline AA & $256(41.29)$ & $251(40.48)$ & & & 1.00 & 1.00 \\
\hline $\mathrm{AC}$ & $290(46.77)$ & $286(46.13)$ & 0.002 & 0.962 & $1.01(0.79-1.28)$ & $1.04(0.79-1.36)$ \\
\hline $\mathrm{CC}$ & 74 (11.94) & 83 (13.39) & 0.540 & 0.463 & $1.14(0.80-1.64)$ & $1.16(0.77-1.74)$ \\
\hline $\mathrm{AC}+\mathrm{CC}$ & $364(58.71)$ & $369(59.52)$ & 0.083 & 0.773 & $1.03(0.82-1.30)$ & $1.06(0.82-1.37)$ \\
\hline $\mathrm{AA}+\mathrm{AC}$ & $546(88.06)$ & $537(86.61)$ & & & 1.00 & 1.00 \\
\hline $\mathrm{CC}$ & 74 (11.94) & 83 (13.39) & 0.591 & 0.442 & $1.14(0.82-1.59)$ & $1.13(0.77-1.67)$ \\
\hline A & $802(64.68)$ & $788(63.55)$ & & & 1.00 & 1.00 \\
\hline $\mathrm{C}$ & $438(35.32)$ & $452(36.45)$ & 0.344 & 0.558 & $1.05(0.89-1.24)$ & $1.03(0.94-1.13)$ \\
\hline \multicolumn{7}{|l|}{ rs2067051 b } \\
\hline $\mathrm{CC}$ & $289(46.61)$ & $274(44.26)$ & & & 1.00 & 1.00 \\
\hline $\mathrm{CT}$ & $274(44.19)$ & $278(44.91)$ & 0.320 & 0.572 & $1.07(0.85-1.35)$ & $1.10(0.84-1.44)$ \\
\hline $\mathrm{TT}$ & $57(9.20)$ & $67(10.82)$ & 1.163 & 0.281 & $1.24(0.84-1.83)$ & $1.26(0.80-1.97)$ \\
\hline $\mathrm{CT}+\mathrm{TT}$ & $331(53.39)$ & $345(55.74)$ & 0.689 & 0.407 & $1.10(0.88-1.38)$ & $1.13(0.87-1.46)$ \\
\hline $\mathrm{CC}+\mathrm{CT}$ & $563(90.81)$ & $552(89.18)$ & & & 1.00 & 1.00 \\
\hline $\mathrm{TT}$ & $57(9.19)$ & $67(10.82)$ & 0.914 & 0.339 & $1.20(0.83-1.74)$ & $1.20(0.78-1.84)$ \\
\hline $\mathrm{C}$ & $852(68.71)$ & $826(66.72)$ & & & 1.00 & 1.00 \\
\hline $\mathrm{T}$ & $388(31.29)$ & $412(33.28)$ & 1.121 & 0.290 & $1.10(0.93-1.30)$ & $1.05(0.96-1.16)$ \\
\hline \multicolumn{7}{|l|}{ rs $2075745^{c}$} \\
\hline AA & $268(43.30)$ & $256(41.09)$ & & & 1.00 & 1.00 \\
\hline AT & $281(45.40)$ & $288(46.23)$ & 0.338 & 0.561 & $1.07(0.85-1.36)$ & $1.11(0.84-1.45)$ \\
\hline $\mathrm{TT}$ & $70(11.30)$ & $79(12.68)$ & 0.803 & 0.370 & $1.18(0.82-1.70)$ & $1.15(0.76-1.75)$ \\
\hline $\mathrm{AT}+\mathrm{TT}$ & $351(56.70)$ & $367(58.91)$ & 0.619 & 0.432 & $1.09(0.87-1.37)$ & $1.12(0.86-1.45)$ \\
\hline $\mathrm{AA}+\mathrm{AT}$ & $549(88.69)$ & $544(87.32)$ & & & 1.00 & 1.00 \\
\hline TT & $70(11.31)$ & 79 (12.68) & 0.554 & 0.457 & $1.14(0.81-1.60)$ & $1.09(0.74-1.62)$ \\
\hline A & $817(65.99)$ & $800(64.21)$ & & & 1.00 & 1.00 \\
\hline $\mathrm{T}$ & $421(34.01)$ & 446 (35.79) & 0.874 & 0.350 & $1.08(0.91-1.28)$ & $1.04(0.95-1.14)$ \\
\hline
\end{tabular}

Abbreviations: HCC, hepatocellular carcinoma; OR, odds ratio; CI, confidence interval; SNPs, single nucleotide polymorphisms.

"Adjusted ORs and 95\% CIs were calculated by the logistic regression model after adjusting for age, gender, smoking status, drinking status, HBsAg status and family history.

${ }^{a}$ Five and one individuals were not successfully genotyped in cases and controls, respectively.

${ }^{\mathrm{b}} \mathrm{Six}$ and one individuals were not successfully genotyped in cases and controls, respectively.

${ }^{c}$ Two and two individuals were not successfully genotyped in cases and controls, respectively.

2 (IGF2) expression [26]. $\mathrm{H} 19$ acts as an oncogene in the above cancers [10], however, is proposed as a tumor suppressor gene in hepatocellular carcinoma [27]. Based on the orthotopic xenograft experiments by Zhang et al. [27], the HCC tissue, with lower $H 19$ expression showed more regressive and metastatic properties. Moreover, their analysis also indicated that, by altering the epigenetic activation of miR-200 with cooperation of the protein complex hnRNP U/PCAF/RNA Pol II, H19 could suppress HCC metastasis and cause EMT. Furthermore, c-Myc could induce the expression of the H19 RNA and bind to the E-boxes near the imprinting control region to facilitate histone acetylation and transcriptional initiation of the $\mathrm{H} 19$ gene in HCC, c-Myc could also down-regulate the expression of IGF2, the reciprocally imprinted gene at the H19/IGF2 locus [28]. Interestingly, the H19 gene was 
Table 3: Stratified analysis of rs2067051 in $\mathrm{H19}$ by participants' characteristics

\begin{tabular}{|c|c|c|c|c|c|c|}
\hline $\begin{array}{l}\text { Stratified } \\
\text { variables }\end{array}$ & Genotypes & $\begin{array}{l}\text { Controls } \\
N=621 \\
\end{array}$ & $\begin{array}{c}\text { Cases } \\
N=625\end{array}$ & $\begin{array}{c}\text { Adjusted OR } \\
(95 \% \mathrm{CI})\end{array}$ & $P^{a}$ & $P^{\mathbf{b}}$ \\
\hline Gender & & & & & 0.384 & 0.518 \\
\hline \multirow[t]{2}{*}{ Males } & $\mathrm{CC}+\mathrm{CT}$ & 490 & 483 & 1.00 & & \\
\hline & TT & 45 & 56 & $1.31(0.82-2.10)$ & & \\
\hline \multirow[t]{2}{*}{ Females } & $\mathrm{CC}+\mathrm{CT}$ & 73 & 69 & 1.00 & & \\
\hline & TT & 12 & 11 & $0.77(0.27-2.19)$ & & \\
\hline HBsAg status & & & & & 0.343 & 0.511 \\
\hline \multirow[t]{2}{*}{ Positive } & $\mathrm{CC}+\mathrm{CT}$ & 180 & 419 & 1.00 & & \\
\hline & TT & 17 & 55 & $1.42(0.79-2.56)$ & & \\
\hline \multirow[t]{2}{*}{ Negative } & $\mathrm{CC}+\mathrm{CT}$ & 383 & 133 & 1.00 & & \\
\hline & TT & 40 & 12 & $0.96(0.48-1.91)$ & & \\
\hline Smoking status & & & & & 0.399 & 0.306 \\
\hline \multirow[t]{2}{*}{ Yes } & $\mathrm{CC}+\mathrm{CT}$ & 321 & 385 & 1.00 & & \\
\hline & TT & 31 & 37 & $1.01(0.57-1.81)$ & & \\
\hline \multirow[t]{2}{*}{ No } & $\mathrm{CC}+\mathrm{CT}$ & 242 & 167 & 1.00 & & \\
\hline & TT & 26 & 30 & $1.48(0.78-2.79)$ & & \\
\hline Drinking status & & & & & 0.175 & 0.132 \\
\hline \multirow[t]{2}{*}{ Yes } & $\mathrm{CC}+\mathrm{CT}$ & 254 & 318 & 1.00 & & \\
\hline & TT & 25 & 29 & $0.86(0.46-1.61)$ & & \\
\hline \multirow[t]{2}{*}{ No } & $\mathrm{CC}+\mathrm{CT}$ & 309 & 234 & 1.00 & & \\
\hline & TT & 32 & 38 & $1.56(0.86-2.83)$ & & \\
\hline Family history & & & & & 0.974 & 0.969 \\
\hline \multirow[t]{2}{*}{ Yes } & $\mathrm{CC}+\mathrm{CT}$ & 78 & 146 & 1.00 & & \\
\hline & TT & 8 & 20 & $1.08(0.39-3.02)$ & & \\
\hline \multirow[t]{2}{*}{ No } & $\mathrm{CC}+\mathrm{CT}$ & 485 & 406 & 1.00 & & \\
\hline & TT & 49 & 47 & $1.20(0.75-1.93)$ & & \\
\hline
\end{tabular}

Abbreviations: OR, odds ratio; CI, confidence interval.

*Adjusted ORs and 95\% CIs were calculated by the logistic regression model after adjusting for age, gender, smoking status, drinking status, HBsAg status and family history.

${ }^{a} P$ values for multiplicative interaction between genetic and environmental factors.

${ }^{\mathrm{b}} P$ values for additive interaction between genetic and environmental factors.

Table 4: Haplotype analysis of $\mathrm{H19}$ rs2839702, rs2067051, and rs2075745 in cases and controls

\begin{tabular}{lllcc}
\hline Haplotype $^{*}$ & Cases, $\boldsymbol{N}=\mathbf{1 2 5 0}(\mathbf{\%})$ & Controls, $\boldsymbol{N}=\mathbf{1 2 4 2}(\mathbf{\%})$ & OR (95\% CI) & $\boldsymbol{P}$ \\
\hline ACA & $788(63.04)$ & $799(64.33)$ & 1.00 & \\
CTT & $413(33.04)$ & $386(31.08)$ & $1.08(0.92-1.29)$ & 0.348 \\
CCT & $29(2.32)$ & $33(2.66)$ & $0.89(0.54-1.48)$ & 0.656 \\
Others & $20(1.60)$ & $24(1.93)$ & $0.85(0.46-1.54)$ & 0.583 \\
\hline
\end{tabular}

Abbreviations: OR, odds ratio; CI, confidence interval.

*The alleles were in the order of rs2839702, rs2067051, and rs2075745. 
Table 5: Combined effect of the 3 polymorphisms in H19 on HCC

\begin{tabular}{lllcrc}
\hline $\begin{array}{l}\text { Number of } \\
\text { risk alleles }\end{array}$ & $\begin{array}{l}\text { Cases (\%) } \\
\boldsymbol{N}=\mathbf{6 2 5}\end{array}$ & $\begin{array}{l}\text { Controls (\%) } \\
\boldsymbol{N}=\mathbf{6 2 1}\end{array}$ & OR (95\% CI) & $\boldsymbol{P}$ & \multirow{2}{*}{ for trend } \\
\hline 0 & $254(41.17)$ & $247(40.10)$ & 1.00 & & 0.409 \\
$1-2$ & $36(5.83)$ & $25(4.06)$ & $0.74(0.42-1.23)$ & 0.221 & \\
$3-4$ & $258(41.82)$ & $267(43.34)$ & $1.06(0.83-1.36)$ & 0.618 & \\
$5-6$ & $69(11.18)$ & $77(12.50)$ & $1.15(0.79-1.66)$ & 0.465 & \\
\hline
\end{tabular}

Abbreviations: OR, odds ratio; CI, confidence interval; SNPs, single nucleotide polymorphisms.

${ }^{*}$ The risk alleles were C, T, T for rs2839702, rs2067051, and rs2075745, respectively.

reported to induce P-glycoprotein expression and multidrug resistance 1 (MDR1)-associated drug resistance at least in liver cancer cells through regulating MDR1 promoter methylation [29]. Additionally, recent studies suggested that individual therapy targeting the miRNA and lncRNA in combination may afford more curative effects on HCC, such as H19 [27]. Despite of extensive evidence, the complex role of $H 19$ in tumorigenesis is still needed to be further elucidated.

Emerging evidence has implied that genetic variants in lncRNAs may modify the risk of multiply tumors [30]. Several molecular epidemiological studies have examined the association between the $H 19$ polymorphisms and the risks of cancers, including breast, bladder, gastric, lung, colorectal and ovarian cancer. Most reports revealed that H19 polymorphisms (rs2107425, rs217727 and rs2839698) were associated with cancer risks [11-16, 31, 32]. Based on the Encyclopedia of DNA Elements (ENCODE) DNase I hypersensitive site (DHS) sequencing data set, H19 polymorphisms (rs2839698 and rs217727) were found in the open chromatin regions that associated with gene regulatory elements, indicating that both of the polymorphisms may affect the binding of transcription factors. ChIP-Seq data from the ENCODE project further demonstrates that rs 217727 is located in a region in where may influence the binding of numerous transcription factors. These results show that it is biologically conceivable for the polymorphisms (rs2839698 and rs217727) in H19 to be potential causal variants that regulate the expression of $H 19$ and further affect cancer. However, we found rs 2839698 was in strong linkage disequilibrium (LD) with rs2839702, rs2067051 and rs2075745 $\left(\mathrm{r}^{2}>0.90\right)$, and the three polymorphisms (rs2839702, rs2067051 and rs2075745) in the role of HCC was far stronger than the above three, according to the bioinformatic we found. Therefore, we aimed to explore whether the H19 polymorphisms were related to the susceptibility of HCC. Nevertheless, in our analysis, no significant association was observed between the $H 19$ polymorphisms and HCC. One reason for this result may be different pathological role of $H 19$ polymorphisms in HCC susceptibility as compare to other cancers. The precise mechanism of $H 19$ polymorphisms action remains unclear, and further investigations are required.
To our knowledge, this is the first investigation of the H19 polymorphisms in the genetic etiology of HCC. Nevertheless, it should be noted that potential selection bias might occur due to the hospital-based design. Besides, although we had more than 600 pairs of HCC cases and controls, the sample size in current study might not be large enough to detect small effects from low penetrance genes. Additionally, only three common variants were assessed, and this study did not provide a global view to the genetic component of $\mathrm{H} 19$ in development of HCC. And as the research further develops, researchers found that rare mutations may have a stronger causative effect. Therefore, the role of rare mutation on H19 in HCC should be explored in the future.

In summary, our study indicated that no association of polymorphisms (rs2839702, rs2067051 and rs2075745) in long non-coding RNA H19 with HCC. Nevertheless, larger population-based case-control studies would be required to confirm the causal genetic polymorphisms in H19 for HCC.

\section{MATERIALS AND METHODS}

\section{Study subjects}

This case-control study was approved by the institutional review board of Guangdong Pharmaceutical University, Guangdong, China. A total of $625 \mathrm{HCC}$ patients and 621 cancer-free controls were enrolled, who all have given written informed consent. HCC patients were newly diagnosed from the Shunde First People's Hospital in Guangdong Province from November 2010 to November 2014. The diagnosis of patients was confirmed by pathological examination or $\alpha$-fetoprotein elevation (> $400 \mathrm{ng} / \mathrm{ml}$ ) combined with imaging examination (magnetic resonance imaging or computerized tomography). During the same period of case enrollment, Controls were selected from a healthy screening at the same hospital. Controls were cancer free and frequency-matched to cases for residential area, age ( \pm 5 years) and gender. For all subjects, data were collected in standardized interview by trained interviewers using a structured questionnaire, including demographic characteristics, smoking status, drinking status and tumor 
Table 6: The associations between the $H 19$ polymorphisms and clinicopathologic characteristics in patients with $\mathrm{HCC}(\mathrm{N}=625)$

\begin{tabular}{|c|c|c|c|c|c|c|c|c|c|}
\hline \multirow[b]{2}{*}{ Genotypes } & \multicolumn{3}{|c|}{ TNM stage } & \multicolumn{3}{|c|}{ Distant metastasis } & \multicolumn{3}{|c|}{ Cancer embolus } \\
\hline & $\mathbf{I}+\mathbf{I I}$ & III + IV & $\begin{array}{l}\text { Adjusted OR } \\
\quad(95 \% \mathrm{CI})\end{array}$ & No & Yes & $\begin{array}{c}\text { Adjusted } \mathrm{OR}^{*}(95 \% \\
\text { CI) }\end{array}$ & No & Yes & Adjusted OR ${ }^{*}(95 \%$ CI $)$ \\
\hline \multicolumn{10}{|l|}{ rs2839702 } \\
\hline $\mathrm{AA}+\mathrm{AC}$ & $\begin{array}{c}69 \\
(15.13)\end{array}$ & $\begin{array}{c}387 \\
(84.87)\end{array}$ & 1.00 & $\begin{array}{c}438 \\
(85.21)\end{array}$ & $\begin{array}{c}76 \\
(14.79)\end{array}$ & 1.00 & $\begin{array}{c}453 \\
(88.65)\end{array}$ & $\begin{array}{c}58 \\
(11.35)\end{array}$ & 1.00 \\
\hline $\mathrm{CC}$ & $\begin{array}{c}16 \\
(23.53)\end{array}$ & $\begin{array}{c}52 \\
(76.47)\end{array}$ & $0.59(0.31-1.09)$ & $\begin{array}{c}69 \\
(88.46)\end{array}$ & $\begin{array}{c}9 \\
(11.54)\end{array}$ & $0.76(0.36-1.63)$ & $73(93.59)$ & $5(6.41)$ & $0.55(0.21-1.42)$ \\
\hline \multicolumn{10}{|l|}{ rs2067051 } \\
\hline $\mathrm{CC}+\mathrm{CT}$ & $\begin{array}{c}71 \\
(84.52)\end{array}$ & $\begin{array}{c}393 \\
(89.73)\end{array}$ & 1.00 & $\begin{array}{c}448 \\
(88.54)\end{array}$ & $\begin{array}{c}77 \\
(90.59)\end{array}$ & 1.00 & $\begin{array}{c}464 \\
(88.55)\end{array}$ & $\begin{array}{c}58 \\
(90.63)\end{array}$ & 1.00 \\
\hline TT & $\begin{array}{c}13 \\
(15.48)\end{array}$ & $\begin{array}{c}45 \\
(10.27)\end{array}$ & $0.63(0.32-1.23)$ & $\begin{array}{c}58 \\
(11.46)\end{array}$ & $8(9.41)$ & $0.76(0.34-1.71)$ & $60(11.45)$ & $6(9.33)$ & $0.79(0.32-1.93)$ \\
\hline \multicolumn{10}{|l|}{ rs2075745 } \\
\hline AA & $\begin{array}{c}30 \\
(13.82)\end{array}$ & $\begin{array}{c}187 \\
(86.18)\end{array}$ & 1.00 & $\begin{array}{c}208 \\
(86.67)\end{array}$ & $\begin{array}{c}32 \\
(13.33)\end{array}$ & 1.00 & $\begin{array}{c}210 \\
(88.61)\end{array}$ & $\begin{array}{c}27 \\
(11.39)\end{array}$ & 1.00 \\
\hline $\mathrm{AT}+\mathrm{TT}$ & $\begin{array}{c}56 \\
(18.12)\end{array}$ & $\begin{array}{c}253 \\
(81.88)\end{array}$ & $0.72(0.44-1.17)$ & $\begin{array}{c}302 \\
(85.07)\end{array}$ & $\begin{array}{c}53 \\
(14.93)\end{array}$ & $1.08(0.67-1.76)$ & $\begin{array}{c}318 \\
(89.58)\end{array}$ & $\begin{array}{c}53 \\
(10.42)\end{array}$ & $0.91(0.53-1.55)$ \\
\hline
\end{tabular}

Abbreviations: OR, odds ratio; CI, 95\% confidence interval; SNPs, single nucleotide polymorphisms.

"Adjusted ORs and $95 \%$ CIs were calculated by the logistic regression model after adjusting for age, gender, smoking status, drinking status, HBsAg status and family history.

family history. The smokers were defined as individuals who had kept smoking almost every day for more than 1 year till the time of interview. Subjects were considered as drinkers, if they consumed 1-2 alcohol drinks per week for more than 1 year. The clinicopathological parameters of cases were collected from hospital clinical records, including HBsAg status, metastasis status, cancer embolus and TNM stage (according to Union for International Cancer Control-American Joint Committee on Cancer, UICC-AJCC, 2002). $5 \mathrm{ml}$ blood sample was obtained from each subject for detection of HBV and DNA extraction.

\section{Variants selection and genotyping}

We used 1000 Genomes Project (http:// www.1000genomes.org) and Ensembl database (http:// asia.ensembl.org/index.html) to identify all single nucleotide polymorphisms in H19, and then SNP info (https://snpinfo.niehs.nih.gov/snpinfo/snpfunc.html), F-SNP software (http://compbio.cs.queensu.ca/F-SNP/) and HaploReg V4.1 tool (http://www.broadinstitute.org/ mammals/haploreg/haploreg.php) were used to choose potentially functional SNPs with minor allele frequency $>0.05$ in Asian populations $(\mathrm{CHB}+\mathrm{JPT}$, based on the 1000GENOMES:pilot_1). A total of three common variants, including rs2839702, rs2067051 and rs2075745, were finally selected in this study based on their potential effects on regulatory motifs (Supplementary Table 1).

Genomic DNA was extracted from peripheral blood leukocytes by TIANamp Genomic DNA Kit. Genotypes were determined by the Sequenom MassARRAY system without knowledge of subjects' status. Five percentage of samples were randomly chosen for duplicately genotyping, with the concordance rate of $100 \%$. The average call rates for the candidate SNPs were over $99 \%$.

\section{Statistical analysis}

Differences in the distribution of demographic characteristics and genotypes of SNPs between the cases and controls were evaluated by using the $t$ test (for continuous variables) or $\chi^{2}$ test (for categorical variables). Hardy-Weinberg equilibrium (HWE) for genotypes in controls was tested by the goodness-of-fit $\chi^{2}$-test. The associations between SNPs and development of HCC were estimated using the adjusted odds ratio (ORs) and their 95\% confidence intervals (CIs), which were calculated in logistic regression models with adjustment for age, gender, HBsAg status, smoking status, drinking status and family history. Multiple genetic models (co-dominant, dominant, recessive and allele models) were assessed in the genetic association analysis. Stratified analysis was conducted by gender, HBsAg status, smoking status, drinking status and family history. Interaction between the polymorphisms and environmental factors were estimated using the multiplicative and additive scales. The $P$ values for multiplicative interaction were calculated using the interaction term included in the multivariate logistic regression models, while the $P$ values for additive interaction were estimated by binomial regression [17]. Haplotype analysis was conducted using the PHASE 2.1 program. The $P$ value of less than 0.05 was considered as statistically significant. All statistical analyses were conducted in the SAS 9.4 software (SAS Institute, Inc., Cary, NC, USA). 


\section{ACKNOWLEDGMENTS}

We would like to express our gratitude to all subjects who participated in this current study.

\section{CONFLICTS OF INTEREST}

The authors declare no conflicts of interest.

\section{FUNDING}

This work was supported by the Science and Technology Plan Project of Guangdong Province (Grant No. 2014A020212307), and Natural Science Foundation of Guangdong Province, China (Grant No. 2016A030313809).

\section{REFERENCES}

1. Ferlay J, Shin HR, Bray F, Forman D, Mathers C, Parkin DM. Estimates of worldwide burden of cancer in 2008: GLOBOCAN 2008. International journal of cancer. 2010; 127:2893-2917.

2. Spolverato G, Vitale A, Cucchetti A, Popescu I, Marques HP, Aldrighetti L, Gamblin TC, Maithel SK, Sandroussi C, Bauer TW, Shen F, Poultsides GA, Marsh JW, et al. Can hepatic resection provide a long-term cure for patients with intrahepatic cholangiocarcinoma? Cancer. 2015; 121:3998-4006.

3. Hirokawa F, Hayashi M, Asakuma M, Shimizu T, Inoue Y, Uchiyama K. Risk factors and patterns of early recurrence after curative hepatectomy for hepatocellular carcinoma. Surg Oncol. 2016; 25:24-29.

4. Wilusz JE, Sunwoo H, Spector DL. Long noncoding RNAs: functional surprises from the RNA world. Genes Dev. 2009; 23:1494-1504.

5. Khaitan D, Dinger ME, Mazar J, Crawford J, Smith MA, Mattick JS, Perera RJ. The melanoma-upregulated long noncoding RNA SPRY4-IT1 modulates apoptosis and invasion. Cancer research. 2011; 71:3852-3862.

6. Calin GA, Liu CG, Ferracin M, Hyslop T, Spizzo R, Sevignani C, Fabbri M, Cimmino A, Lee EJ, Wojcik SE, Shimizu M, Tili E, Rossi S, et al. Ultraconserved regions encoding ncRNAs are altered in human leukemias and carcinomas. Cancer cell. 2007; 12:215-229.

7. Braconi C, Valeri N, Kogure T, Gasparini P, Huang N, Nuovo GJ, Terracciano L, Croce CM, Patel T. Expression and functional role of a transcribed noncoding RNA with an ultraconserved element in hepatocellular carcinoma. Proceedings of the National Academy of Sciences of the United States of America. 2011; 108:786-791.

8. Brannan CI, Dees EC, Ingram RS, Tilghman SM. The product of the H19 gene may function as an RNA. Mol Cell Biol. 1990; 10:28-36.
9. Ayesh S, Matouk I, Schneider T, Ohana P, Laster M, AlSharef W, De-Groot N, Hochberg A. Possible physiological role of H19 RNA. Molecular carcinogenesis. 2002; 35:63-74.

10. Matouk IJ, DeGroot N, Mezan S, Ayesh S, Abu-lail R, Hochberg A, Galun E. The H19 non-coding RNA is essential for human tumor growth. PLoS One. 2007; 2:e845.

11. Yang C, Tang R, Ma X, Wang Y, Luo D, Xu Z, Zhu Y, Yang L. Tag SNPs in long non-coding RNA H19 contribute to susceptibility to gastric cancer in the Chinese Han population. Oncotarget. 2015; 6:15311-15320. https://doi. org/10.18632/oncotarget.3840.

12. Xia Z, Yan R, Duan F, Song C, Wang P, Wang K. Genetic Polymorphisms in Long Noncoding RNA H19 Are Associated With Susceptibility to Breast Cancer in Chinese Population. Medicine (Baltimore). 2016; 95:e2771.

13. Verhaegh GW, Verkleij L, Vermeulen SH, den Heijer M, Witjes JA, Kiemeney LA. Polymorphisms in the H19 gene and the risk of bladder cancer. Eur Urol. 2008; 54:1118-1126.

14. Song H, Ramus SJ, Kjaer SK, DiCioccio RA, Chenevix-Trench G, Pearce CL, Hogdall E, Whittemore AS, McGuire V, Hogdall C, Blaakaer J, Wu AH, Van Den Berg DJ, et al. Association between invasive ovarian cancer susceptibility and 11 best candidate SNPs from breast cancer genome-wide association study. Human molecular genetics. 2009; 18:2297-2304.

15. Li S, Hua Y, Jin J, Wang H, Du M, Zhu L, Chu H, Zhang Z, Wang M. Association of genetic variants in lncRNA H19 with risk of colorectal cancer in a Chinese population. Oncotarget. 2016; 7:25470-25477. https://doi.org/10.18632/ oncotarget.8330.

16. Gong WJ, Yin JY, Li XP, Fang C, Xiao D, Zhang W, Zhou $\mathrm{HH}, \mathrm{Li}$ X, Liu ZQ. Association of well-characterized lung cancer lncRNA polymorphisms with lung cancer susceptibility and platinum-based chemotherapy response. Tumour biology. 2016; 37:8349-8358.

17. Wacholder S. Binomial regression in GLIM: estimating risk ratios and risk differences. American journal of epidemiology. 1986; 123:174-184.

18. Hibi K, Nakamura H, Hirai A, Fujikake Y, Kasai Y, Akiyama S, Ito K, Takagi H. Loss of H19 imprinting in esophageal cancer. Cancer research. 1996; 56:480-482.

19. Luo M, Li Z, Wang W, Zeng Y, Liu Z, Qiu J. Long noncoding RNA H19 increases bladder cancer metastasis by associating with EZH2 and inhibiting E-cadherin expression. Cancer letters. 2013; 333:213-221.

20. Cui H, Onyango P, Brandenburg S, Wu Y, Hsieh CL, Feinberg AP. Loss of imprinting in colorectal cancer linked to hypomethylation of H19 and IGF2. Cancer research. 2002; 62:6442-6446.

21. Berteaux N, Lottin S, Monte D, Pinte S, Quatannens B, Coll J, Hondermarck H, Curgy JJ, Dugimont T, Adriaenssens E. H19 mRNA-like noncoding RNA promotes breast cancer cell proliferation through positive control by E2F1. The Journal of biological chemistry. 2005; 280:29625-29636. 
22. Matouk IJ, Halle D, Raveh E, Gilon M, Sorin V, Hochberg A. The role of the oncofetal H19 lncRNA in tumor metastasis: orchestrating the EMT-MET decision. Oncotarget. 2016; 7:3748-3765. https://doi.org/10.18632/ oncotarget.6387.

23. Kallen AN, Zhou XB, Xu J, Qiao C, Ma J, Yan L, Lu L, Liu C, Yi JS, Zhang H, Min W, Bennett AM, Gregory RI, et al. The imprinted H19 lncRNA antagonizes let-7 microRNAs. Molecular cell. 2013; 52:101-112.

24. Raveh E, Matouk IJ, Gilon M, Hochberg A. The H19 Long noncoding RNA in cancer initiation, progression and metastasis - a proposed unifying theory. Molecular cancer. 2015; 14:184.

25. Liang WC, Fu WM, Wong CW, Wang Y, Wang WM, Hu GX, Zhang L, Xiao LJ, Wan DC, Zhang JF, Waye MM. The lncRNA H19 promotes epithelial to mesenchymal transition by functioning as miRNA sponges in colorectal cancer. Oncotarget. 2015; 6:22513-22525. https://doi. org/10.18632/oncotarget.4154.

26. Berteaux N, Aptel N, Cathala G, Genton C, Coll J, Daccache A, Spruyt N, Hondermarck H, Dugimont T, Curgy JJ, Forne T, Adriaenssens E. A novel H19 antisense RNA overexpressed in breast cancer contributes to paternal IGF2 expression. Mol Cell Biol. 2008; 28:6731-6745.

27. Zhang L, Yang F, Yuan JH, Yuan SX, Zhou WP, Huo XS, $\mathrm{Xu}$ D, Bi HS, Wang F, Sun SH. Epigenetic activation of the MiR-200 family contributes to H19-mediated metastasis suppression in hepatocellular carcinoma. Carcinogenesis. 2013; 34:577-586.

28. Barsyte-Lovejoy D, Lau SK, Boutros PC, Khosravi F, Jurisica I, Andrulis IL, Tsao MS, Penn LZ. The c-Myc oncogene directly induces the H19 noncoding RNA by allele-specific binding to potentiate tumorigenesis. Cancer research. 2006; 66:5330-5337.

29. Tsang WP, Kwok TT. Riboregulator H19 induction of MDR1-associated drug resistance in human hepatocellular carcinoma cells. Oncogene. 2007; 26:4877-4881.

30. Du M, Wang W, Jin H, Wang Q, Ge Y, Lu J, Ma G, Chu H, Tong N, Zhu H, Wang M, Qiang F, Zhang Z. The association analysis of lncRNA HOTAIR genetic variants and gastric cancer risk in a Chinese population. Oncotarget. 2015; 6:31255-31262. https://doi.org/10.18632/oncotarget.5158.

31. Hua Q, Lv X, Gu X, Chen Y, Chu H, Du M, Gong W, Wang $\mathrm{M}$, Zhang Z. Genetic variants in lncRNA H19 are associated with the risk of bladder cancer in a Chinese population. Mutagenesis. 2016; 31:531-538.

32. Butt S, Harlid S, Borgquist S, Ivarsson M, Landberg G, Dillner J, Carlson J, Manjer J. Genetic predisposition, parity, age at first childbirth and risk for breast cancer. BMC research notes. 2012; 5:414. 